\title{
Synthesis, Characterization Antimicrobial and Antioxidant Activities of 2,4-dihydroxybenzaldehyde-4-phenyl-3-thiosemicarbazone (DHBPTSC) and its Pd(II), Ni(II)dppm Mixed Ligand and Cu(II) Complex having Heterocyclic Bases
}

\author{
V. Asha Kumar ${ }^{1}$, Y. Sarala ${ }^{2}$, Asha Siddikha ${ }^{3}$, S. Vanitha ${ }^{4}$, S. Babu ${ }^{5}$, A. Varada Reddy ${ }^{1 *}$ \\ ${ }^{1}$ Analytical Division, Department of Chemistry, Sri Venkateswara University, Tirupati 517502, India. \\ ${ }^{2}$ Department of Chemistry, CBIT, Hyderabad, India. \\ ${ }^{3}$ Department of Chemistry, JNTUH, Hyderabad, India. \\ ${ }^{4}$ Department of Chemistry, JNTUA, Anantapur, India. \\ ${ }^{5}$ Department of Physics, Sri Venkateswara University, Tirupati, India.
}

\begin{tabular}{l}
\hline ARTICLE INFO \\
\hline Article history: \\
Received on: 06/07/2017 \\
Accepted on: 28/02/2018 \\
Available online: $29 / 04 / 2018$
\end{tabular}

Key words:

Antimicrobial,

Antioxidant activity, 2,

4,-dihydroxybenzaldehyde,

Electronic, FT-IR, NMR and

EPR spectral studies.

\begin{abstract}
A series of four new $\mathrm{Pd}(\mathrm{II})$, [Ni(II)dppm], [Cu(II)bipy] and [Cu(II)phen] complexes of 2,4-dihydroxybenzaldehyde-4phenyl-3-thiosemicarbazone (DHBPTSC). The DHBPTSC (ligand) and complexes were established by using means of IR, ${ }^{1} \mathrm{H}$ NMR, Mass, electronic, EPR spectra and elemental analysis discussed. The FT-IR spectral data intimate the coordination of sulphur and azomethine nitrogen with the central metal ion. The EPR spectra of absorbance were observed for $\mathrm{Cu}(\mathrm{II})$ bipy and $\mathrm{Cu}(\mathrm{II})$ phen complexes the $\mathrm{g}$ values $\mathrm{g}_{\|}=2.126$ and $\mathrm{g}_{\mathrm{l}}=2.108$, respectively. The $\mathrm{g}$ values are found in both the complexes had suggested elongated tetragonal geometry for the molecules. These compounds were further tested with antibacterial, antifungal and antioxidant activities.
\end{abstract}

\section{INTRODUCTION}

In the opinion of during continue infrequent depraved continuing interest in the coordination behavior of thiosemicarbazones. Past decades mainly thiosemicarbazones have exposed class of compounds have multi-donor ligands still growing attracts in the research group. This class of compounds has absorbed in the pharmacological and biological activity of thiosemicarbazone and several transition metal complexes have received considerable attention in the chemistry.

\section{${ }^{*}$ Corresponding Author}

A. Varada Reddy, Analytical Division, Department of Chemistry, Sri

Venkateswara University, Tirupati 517502, India.

E-mail:ammireddyv@yahoo.co.in
Thiosemicarbazones have shown biology importance because of their variable biological applications as some of them have present antitumor, antiviral, antifungal, antibacterial and antimalarial suitability (Scovill et al., 1982; Hu et al., 2006; Belwal et al., 1999; Casas et al., 2000; Offiong et al., 1994; Singh et al., 2001; Garcia et al., 2003; Mishra et al., 2006; Prasad and Agarwal, 2007; Singh et al., 2000). They reported on a wide range of activities such as identify tumors, bacteria and fungi activities (Kizilcikh et al., 2004). Particular properties of these compounds due to their chelating ability and bonding modes to the central metal atom. The imine group $(-\mathrm{N}=\mathrm{CH}-)$ becomes a suitable donor for coordination to grant. The versatile ligands to show chelating behavior and various biological properties (Chandra et al., 2001). In the course of these synthetic studies were also observed under certain conditions carbonyl thiosemicarbazones undergo in cyclization 
reaction many cases, thiosemicarbazones act as bidentate and tridentate ligands that coordinate to through Sulphur, Azomethine nitrogen and heteroatom and their coordinative behavior followed depends on the transition metal ions occupy (Campbell et al., 1975; Padhye et al., 1985; West et al., 1993; Singh et al., 2006; Sahin et al., 2009; Bermejo et al., 2001). A strong interacts with the heterocyclic Aldehydes or ketones depending upon coordination with ligand and complexes has stable in bioactivities (John et al., 2004; Belicchi-Ferrari et al., 2005; Gulea et al., 2004; Birca et al., 2004). In the present paper, we report synthesis, characterization of newly synthesized metal compounds $\mathrm{Pd}(\mathrm{II}), \mathrm{Ni}(\mathrm{II}) \mathrm{dppm}$ and [Cu(II)bipyl/phen] complexes of 2,4-dihydroxybenzaldehyde-4-phenyl-3-thiosemicarbazone. By using spectroscopic techniques ${ }^{1}$ NMR, Mass, FT-IR, UV-Vis and EPR spectra. Furthermore, the antioxidant, antibacterial and antifungal activities were evaluated.

\section{EXPERIMENTAL}

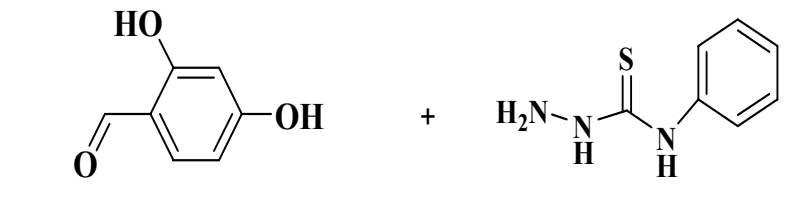
2,4-Dihydroxybenzaldehyde

4-Phenyl-3-thiosemicarbazide

\section{Starting materials and methods}

The chemicals were reagent grade without refinement of the preparation of DHBPTSC and 1 complexes. Palladium (II) chloride, bisdiphenylphospinomethan(dppm), 2,2 bipyridyle(bipy), 1,10-phenanthroline (phen), 2,4-dihydroxybenzaldehyde were obtained from Sigma-Aldrich. 4-phenyl-3-thiosemicarbazide was purchased from Alfa-Aesar chemicals. Whereas copper (II) acetate, nickel (II) chloride, were buying from Sd-fine chemicals.

\section{Synthesis of ligand (DHBPTSC)}

Two of the reactants 2,4-dihydroxybenzaldehyde (1.381 $\mathrm{g}, 0.01 \mathrm{~mol}$ ) and 4-phenyl-3-thiosemicarbazide (1.673 g, $0.01 \mathrm{~mol})$ were separately dissolved in $20 \mathrm{~mL}$ of ethanol and subsequently, they were mixed. To this mixture 2 drops of glacial acetic was added, this mixture was refluxed for $6 \mathrm{~h}$ at $60-70^{\circ} \mathrm{C}$. The obtained yellow color precipitate is collected thoroughly filtered off washed with ethanol. Finely dried over $\mathrm{P}_{4} \mathrm{O}_{10}$. Purity was checked by thin layer chromatography (TLC) techniques. The synthesis rote is Scheme 1 .

Scheme 1: General synthesis of DHBPTSC.

\section{Synthesis of complexes}

Synthesis of $\mathrm{NiCl}_{2}\left(\mathrm{PPh}_{2}-\mathrm{CH}_{2}-\mathrm{PPh}_{2}\right)$

To $10 \mathrm{~mL}$ of DHBPTSC (0.574 g, $0.002 \mathrm{~mol})$ was dissolved in acetonitrile solution and $10 \mathrm{~mL}$ of acetonitrile solution containing solid $\mathrm{NiCl}_{2}$ salt $(0.474 \mathrm{~g}, 0.002 \mathrm{~mol})$ and $3 \mathrm{~mL}$ of the $\mathrm{Et}_{3} \mathrm{~N}$ base were added and stirred for one hour. To the reaction mixture under stirring, solid $\mathrm{PPh}_{2}-\mathrm{CH}_{2}-\mathrm{PPh}_{2}(0.768 \mathrm{~g}, 0.002 \mathrm{~mol})$ was added and further continued stirring for 4-5 h. Finally, the obtained red color compound was allowed to evaporate at room temperature to yielded which afforded red crystals along with the formation of $\mathrm{Et}_{3} \mathrm{NH}^{+} \mathrm{Cl}^{-}$salt.

\section{Synthesis of $\mathrm{PdCl}_{2}-$ DHBPTSC complex}

The hot methanolic solution $10 \mathrm{~mL}$ of DHBPTSC $(0.574$ g, $0.002 \mathrm{~mol}), 5 \mathrm{~mL}$ of a methanolic solution of $\mathrm{PdCl}_{2}(0.0177$ $\mathrm{g}, 0.0001 \mathrm{~mol})$ were slowly dissolved and then mixed. This mixture was refluxed for $6-7 \mathrm{~h}$ at $60-70^{\circ} \mathrm{C}$ to get a brown colored solution. The progress of the reaction was monitored by TLC. The solution was further evaporated slowly on cooled to stand at room temperature. To get a brown colored precipitate, the obtained precipitate was separated by filtration and washed with hot ethanol and ultimately dried.

\section{Synthesis of [Cu(II)bipy/phen]}

The new Copper(II) mixed ligand complexes were synthesized general procedure. To $10 \mathrm{~mL}$ of DHBPTSC $(0.574 \mathrm{~g}$,
$0.002 \mathrm{~mol})$ in hot ethanol solution was added an ethanolic solution of $\mathrm{Cu}(\mathrm{OAc})_{2} \cdot \mathrm{H}_{2} \mathrm{O}(0.398 \mathrm{~g}, 0.002 \mathrm{~mol})$ which constant stirring for 4-5 h, To this mixture, the solid heterocyclic base ( $0.002 \mathrm{~mol}$, bipy/ phen) was added and then content continued stirring for another one hour. The obtained green colored precipitate was formed and filtered. Finally, washed in ethanol ultimately dried.

\section{Physical measurement}

${ }^{1} \mathrm{HMR}$ spectrum of the DHBPTSC (L) was recorded on Bruker Bio spin AG-400 MHz (School of Chemistry, University of Hyderabad) using DMSO-d ${ }^{6}$ with TMS an internal reference compound. Mass spectra of the ligand was carried out in the University of Hyderabad on a Quattro LC-Micro mass. Elemental analysis (CHN) was executed by using FLASH 1112 series. FT-IR spectra ( $\mathrm{KBr}$ pellet) were obtained in the solid state the range of $4000-400 \mathrm{~cm}^{-1}$ utilizing a thermo scientific nicolet -380 spectrophotometers. The electronic spectra were recorded with the help of a UV Shimadzu-3600 spectrometer. EPR spectra of the polycrystalline sample at $298 \mathrm{k}$ Bruker-ER073 apparatus equipped with an EMX micro $\mathrm{X}$ source for $\mathrm{X}$ band measurement were these compounds were used to carry out.

\section{Biological studies}

Collection of microorganisms

The microorganisms such as Bacillus subtilis (B. subtilis), Escherichia Coli (E. coli) Pseudomonas (P.fluorescencs), 
Staphylococcus aureus (S. aureus) and fungal development of Aspergillus niger, Penicillin, A. Ravis and A. Mucor) were obtained from Institute of Microbial Technology (IMTECH), Chandigarh and Department of Biochemistry, Sri Venkateswara University, Tirupati, India. In the present study were used for testing antimicrobial organisms. The bacteria were maintained on nutrient broth $(\mathrm{NB})$ at $37^{\circ} \mathrm{C}$ and fungus was maintained on Potato dextrose agar (PDA) at $28^{\circ} \mathrm{C}$.

\section{Antimicrobial activity}

The synthesized DHBPTSC (ligand) and its Pd(II), Ni(II) $\mathrm{dppm}$ and $[\mathrm{Cu}($ bipy/phen) $]$ complexes are subjected to in-vitro antimicrobial and antifungal activity. The antimicrobial activity of different compounds described using agar diffusion method according to Goñi et al. (2009) with modifications. Each sterile Petri plate $(90 \mathrm{mn})$ was prepared with $20 \mathrm{~mL}$ of nutrient agar and PDA medium. After solidifying, $100 \mu \mathrm{L}$ of bacterial apprehension was spread on the plates. After 5 minutes, a sterile filter paper disc ( $6 \mathrm{mn}$ ) containing $5 \mu \mathrm{l}$ of the compound was placed on the surface of each plate. Afterward, the microbial plates were incubated at $37^{\circ} \mathrm{C}$ for $24 \mathrm{~h}$ bacterial development and at $28^{\circ} \mathrm{C}$ for $48 \mathrm{~h}$ for fungal produce. The antimicrobial activity of various compounds represented by measuring the diameter of inhibition zone (DIZ) in $\mathrm{mm}$ streptomycin and fluconazole drug was served reference drug.

\section{Anti-oxidant activity}

The free radical scavenging activity of ligand and the $\mathrm{Pd}(\mathrm{II}), \mathrm{Ni}(\mathrm{II}) \mathrm{dppm}, \mathrm{Cu}(\mathrm{II})$-bipy and $\mathrm{Cu}(\mathrm{II})$-phen complexes compounds was measured with bleaching of a colored methanolic solution of 1,1-diphenyl-1-picrylhydrazyl (DPPH). $1 \mathrm{ml}$ of various concentrations of the ligand and metal complex compounds $(25,50,75$, and $100 \mu \mathrm{g} / \mathrm{mL})$ dissolved in $4 \mathrm{ml}$ of $0.004 \%(\mathrm{w} / \mathrm{v})$ methanol solution of DPPH. After a $30 \mathrm{~min}$ incubation at room temperature, the absorbance was read against blank at $517 \mathrm{~nm}$. The presence of inhibition (\%) of formation of free radical from DPPH was determined by the following equation:

$\%$ of scavenging $=(($ A control - A sample $) /($ A control $)) \times 100$,

where A control is the absorbance of the regulate reaction (containing all reagents expects the test compound) and A sample is the absorbance of the test compounds Vitamin- $\mathrm{C}$ was used and citation. The test was carried in triplicate.

\section{RESULTS AND DISCUSSION}

\section{${ }^{1} \mathrm{NMR}$ and mass spectra}

${ }^{1} \mathrm{H}$ NMR spectra of DHBPTSC is recorded in DMSO$\mathrm{d}_{6}$ solution using TMS internal reference compound. ${ }^{1} \mathrm{H}$ NMR spectra is presented in Figure 1. The data analysis represented as follows. The peak at $11.57 \mathrm{ppm}$ attributes the N-H functionality attached to azomethine. The singlet signal at $9.91 \mathrm{ppm}$ is the corresponding to the proton of $\mathrm{N}-\mathrm{H}$ group appear in between phenyl and $\mathrm{C}=\mathrm{S}$ groups. The phenolic ortho $-\mathrm{OH}$ proton shows a singlet at $8.36 \mathrm{ppm}$. Whereas, the signal at $7.85 \mathrm{ppm}$ represents the phenolic para $-\mathrm{OH}$ proton. The proton attached to azomethine moiety resonates at $8.10 \mathrm{ppm}$. The signals appear in the range of 7.56-6.28 ppm are attributed to eight aromatic protons. Yellow color solid: M.P:215 ${ }^{\circ} \mathrm{C}:{ }^{1} \mathrm{HNMR}:(400 \mathrm{MHz}) \delta(\mathrm{ppm}) \mathrm{DMSO}-\mathrm{d}_{6}$ : $\delta 11.57(1 \mathrm{H}, \mathrm{s}, \mathrm{NH}) ; 9.91(1 \mathrm{H}, \mathrm{s}, \mathrm{NH}), \delta 8.36(\mathrm{lH}, \mathrm{s},-\mathrm{OH}), \delta 7.85$ $(1 \mathrm{H}, \mathrm{d},-\mathrm{OH}), 7.56(3 \mathrm{H}, \mathrm{d}, J=8.0 \mathrm{~Hz}, \mathrm{Ar}-\mathrm{H}) 7.35(3 \mathrm{H}, \mathrm{d}, J=8.0$ $\mathrm{Hz}, \mathrm{Ar}-\mathrm{H}), 7.17(1 \mathrm{H}, \mathrm{t}, J=8.0 \mathrm{~Hz}, \mathrm{Ar}-\mathrm{H}), 7.17(1 \mathrm{H}, \mathrm{d}, J=8.0$ $\mathrm{Hz}, \mathrm{Ar}-\mathrm{H}), 6.32-6.28$ (2H, m, Ar-H): The mass spectrum of ligand presented in Figure 2 owed a molecular ion $\mathrm{m} / \mathrm{z}(\mathrm{M}+1)$ peaks at $287.34 \mathrm{amu}$ corresponding to species $\left(\mathrm{C}_{14} \mathrm{H}_{13} \mathrm{~N}_{3} \mathrm{O}_{2} \mathrm{~S}\right)$ it prove in good conformance with the suggested structure of the formula. Elemental and chemical analysis data are demonstrated in Table 1.

Table 1: Analytical data for the ligand and its $\mathrm{Pd}(\mathrm{II}), \mathrm{Ni}(\mathrm{II}) \mathrm{dppm}$ and [Cu(II)bipy/phen] complexes.

\begin{tabular}{|c|c|c|c|c|c|c|c|c|}
\hline \multirow{2}{*}{ S. No } & \multirow{2}{*}{ Compounds } & \multirow{2}{*}{ Color } & \multirow{2}{*}{ M.Wt } & \multirow{2}{*}{ M.P $\left({ }^{\circ} \mathrm{C}\right)$} & \multirow{2}{*}{$\%$ Yield } & \multicolumn{3}{|c|}{ Elemental analyses data(\%) Expt. (calculated) } \\
\hline & & & & & & $\mathbf{C}$ & $\mathbf{H}$ & $\mathbf{N}$ \\
\hline 1 & Ligand & Yellow & 287.07 & 215 & 75 & $58.45(58.41)$ & $4.62(4.59)$ & $14.48(14.47)$ \\
\hline 2 & Pd(II) & Orange & 680.05 & $>300$ & 62 & $49.32(49.35)$ & $3.81(3.80)$ & $12.45(12.42)$ \\
\hline 3 & Ni(II)dppm & Redish brown & 729.13 & $>300$ & 65 & $64.26(64.16)$ & $4.75(4.81)$ & $5.68(5.71)$ \\
\hline 4 & $\mathrm{Cu}(\mathrm{II})$ bipy & Green & 530.07 & $>300$ & 61 & $56.62(56.58)$ & $4.31(4.34)$ & 13.65 (13.67) \\
\hline 5 & $\mathrm{Cu}(\mathrm{II})$-phen & Light Green & 506.07 & $>300$ & 61 & $58.81(58.80)$ & $4.23(4.25)$ & $13.07(13.11)$ \\
\hline
\end{tabular}

\section{FT-IR spectra}

The IR spectral investigation is one of the evidence to find out the structural confirmation of the synthesized compounds by the identifying the bands corresponding to the important functional groups. The conformance specification vibrational band with structural results provide evidence the ligand coordination through complexation. The significant vibrational bands corresponding to the DHBPTSC and its Pd(II), Ni(II) dppm, $\mathrm{Cu}$ (II)-bipy and $\mathrm{Cu}(\mathrm{II})$-phen are assigned and compared carefully. The important vibrational bands are carefully assigned and presented in Table 2. The spectra of DHBPTSC is confirmed on the absence of the band in the range from $2853-2924 \mathrm{~cm}^{-1}$ which indicates the presence of thione form (Sampath et al., 2013) and appearance of strong IR band of ligand at $1603 \mathrm{~cm}^{-1}$ confirms the conversion of the carbonyl group to imine group. Further the coordination of the ligand with metal complexes of $\mathrm{Pd}(\mathrm{II}), \mathrm{Ni}$ (II) dppm $\mathrm{Cu}$ (II)-bipy, $\mathrm{Cu}$ (II)-phen complexes, the appearance of shift of this band at $1627 \mathrm{~cm}^{-1}, 1601 \mathrm{~cm}^{-1}, 1600 \mathrm{~cm}^{-1}$ and $1654 \mathrm{~cm}^{-1}$ in the complexes corresponding to the coordination of azomethine $v(\mathrm{HC}=\mathrm{N})$ respectively, shown in Figure 3. It indicating the involvement of the azomethine nitrogen in equalizing to the metal ion. Coordination of azomethine nitrogen, in turn, affects the 
band order between the carbon and nitrogen shift of vibrations to lower frequencies (Yudhvir et al., 1983; West et al., 1988). The participation of thione $(\mathrm{C}=\mathrm{S})$ functional group of ligand has shown IR band at $833 \mathrm{~cm}^{-1}$, after coordination with the central metal ion is observed from the appearance of vibrational band at $847 \mathrm{~cm}^{-1}, 854$ $\mathrm{cm}^{-1}, 849 \mathrm{~cm}^{-1}$, and $848 \mathrm{~cm}^{-1}$ in the spectra of $\mathrm{Pd}(\mathrm{II}), \mathrm{Ni}(\mathrm{II})-\mathrm{dppm}$,
$\mathrm{Cu}$ (II)-bipy, $\mathrm{Cu}$ (II)-phen complexes, respectively, (Lobana et al., 2014; Lobanaa et al., 2013). The metal-nitrogen bond formation is again confirmed with the presence of weak yet new bonds at $466 \mathrm{~cm}^{-1}, 485 \mathrm{~cm}^{-1}, 466 \mathrm{~cm}^{-1}$ are designated to (Pd(II)-N), (Ni(II) dppm-N), (Cu(II)-bipy-N), and $\mathrm{Cu}(\mathrm{II})-$ phen-N) complexes are, respectively.

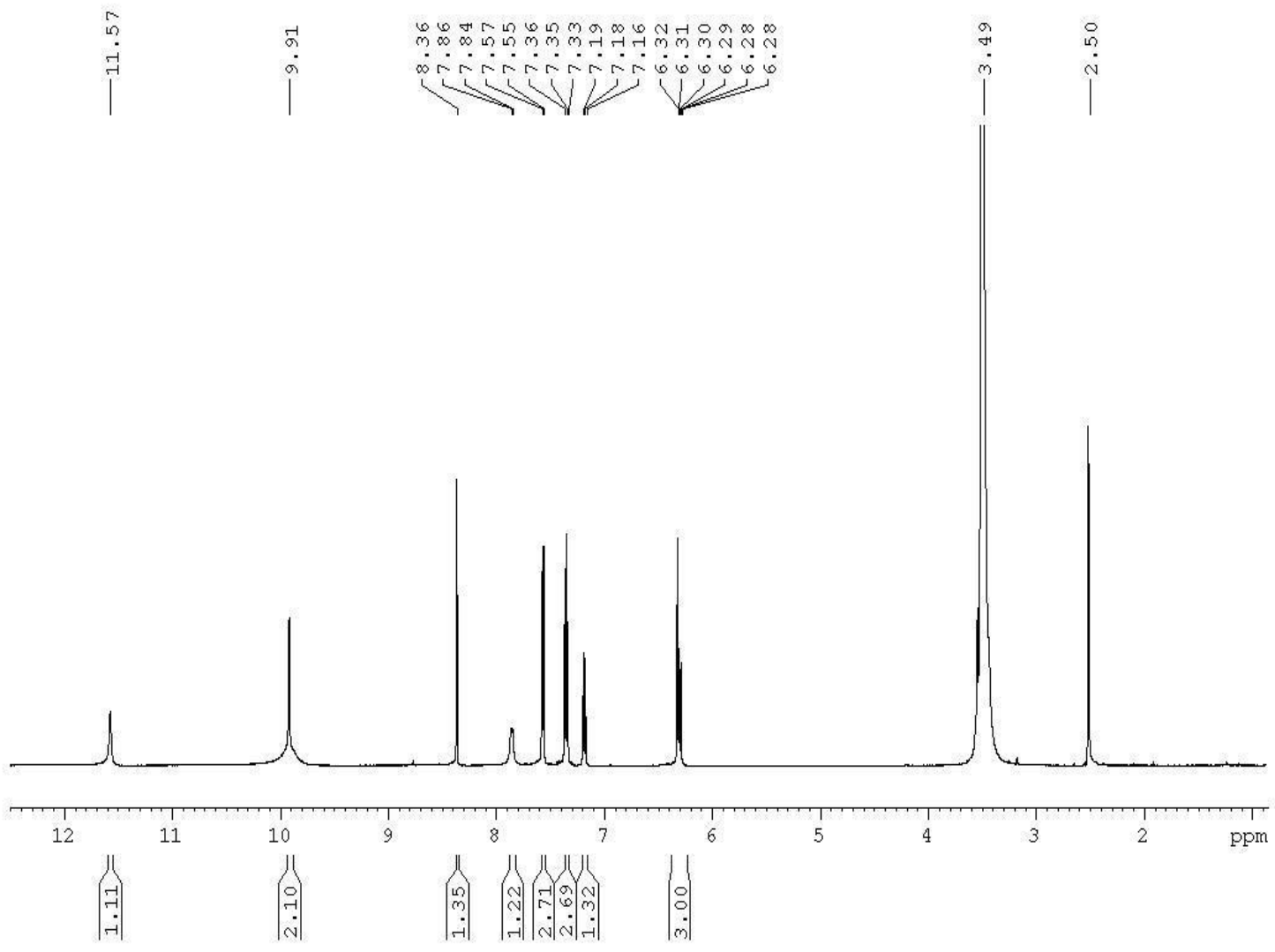

Fig. 1: ${ }^{1} \mathrm{H}$ NMR spectrum of the DHBPTSC.

Table 2: IR values with assignments for the DHBPTSC, Pd(II), Ni(II)dppm and $[\mathrm{Cu}(\mathrm{II})$ bipy] and $[\mathrm{Cu}(\mathrm{II})$ phen $]$ complexes.

\begin{tabular}{cccccc}
\hline Ligand & Pd (II) & Ni(II)-dppm & Cu(II)-bipy & Cu(II)-phen & Assignments \\
\hline 3318 & 3347 & 3051 & 3320 & 3403 & vsyN-H \\
1603 & 1627 & 1601 & 1600 & 1654 & $v(\mathrm{C}=\mathrm{N})$ \\
852 & 847 & 854 & 849 & 848 & $v(\mathrm{C}=\mathrm{S})$ \\
487 & 466 & 485 & 481 & 425 & $\mathrm{M}-\mathrm{N}$ \\
\hline
\end{tabular}

\section{Electronic absorption spectra}

The UV-Vis spectra of the ligand with corresponding complexes of $\mathrm{Cu}(\mathrm{II})$-bipy, $\mathrm{Cu}(\mathrm{II})$-phen, and $\mathrm{Pd}(\mathrm{II})$ were recorded in methanolic solution. Whereas $\mathrm{Ni}(\mathrm{II}) \mathrm{dppm}$ complexes were collected in acetonitrile solution. The absorption pattern of the ligand is comparable with exact types of thiosemicarbazones ligands reported (Jagadeesh et al., 2015). The display a group of bands at 256, 293, and $306 \mathrm{~nm}$ corresponds to the $\pi-\pi *$ transitions. All the complexes display similar bands corresponding to the intra-ligand transitions below $350 \mathrm{~nm}$ and an expected blue shift was observed compared to the ligand. The electronic transition found in thiosemicarbazones due to imine function was shifted on complexation. The $\mathrm{Cu}$ (II) mixed ligand complex with 2,2 bipyridyl and 1,10-phenanthroline ancillary ligands exhibit a broad band with tolerable intensity near $402 \mathrm{~nm}$ corresponding to the ligand to metal charge transfer transitions (Lobana et al., 2014). The Ni(II) complexes with $\left(\mathrm{PPh}_{2}-\mathrm{CH}_{2}-\mathrm{PPh}_{2}\right)$ as ancillary ligand and $\mathrm{Pd}(\mathrm{II})$ complex are also showing a similar kind of absorption bands parallel to $\mathrm{Cu}$ (II)bipy and $\mathrm{Cu}$ (II)phen complex in the region of $400-450 \mathrm{~nm}$, which are also attributed to transitions. The spectrum of two complexes $\mathrm{Cu}$ (II)-bipy and $\mathrm{Cu}$ (II)-phen show a red shift approximately $30 \mathrm{~nm}$ was observed for ligand centered bands, but in case of $\mathrm{Ni}$ (II)-dppm and $\mathrm{Pd}(\mathrm{II})$ complexes has the maximum red shift was only about $15 \mathrm{~nm}$. This observation transparently indicates the stabilization of exited state in complexes. The Ni(II)dppm complex as ancillary ligand confirms square planar nature of the complex and $\mathrm{Pd}(\mathrm{II})$ complex suggest a square planar geometry involving transition in the spectra shown in Figures 4 and 5, respectively. 


\title{
LCMS-2010A DATA REPORT SHIMADZU
}

\author{
User : Admin \\ Sample : :AKL4/3 \\ Inj. Volume $\quad: 5.000$ \\ Data Name $\quad$ :E:DatalAKL4-3-APCI-POS1.qld \\ Method Name $\quad$ : C:LCMSsolutionlUserlMethodlesi.qlm
}

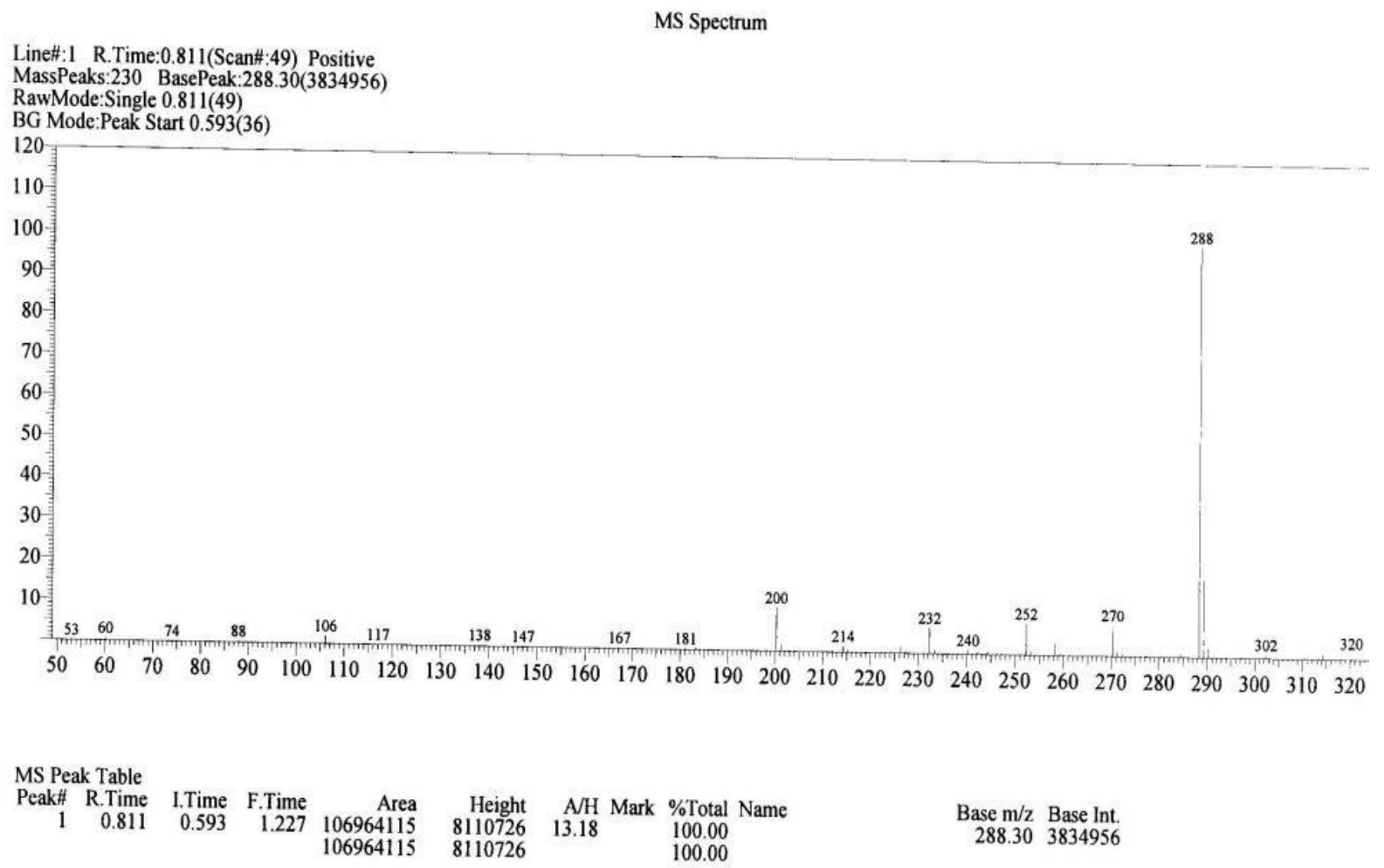

Fig. 2: Mass spectrum of the DHBPTSC.

\section{Electron paramagnetic resonance spectra (EPR)}

EPR spectra of the $\mathrm{Cu}(\mathrm{II})$ complex of 2,4-dihydroxybenzaldehyde-4-phenyl-3-thiosemicarbazone were recorded in polycrystalline samples at $298 \mathrm{~K}$ on $\mathrm{X}$ band at a frequency of $9.68 \mathrm{GHz}$ under the magnetic field stamina of 320 G. room temperature X-band. The spectrum of $\mathrm{Cu}$ (II)-bipy complex-1 and $\mathrm{Cu}(\mathrm{II})$-phen complexes-2 are presented in Figures 6 and 7, respectively. The spectra of the complexes have shown some variations with a change in the ligand all the complexes exhibit a superposition of very broad constituent due to strong dipole-dipole interactions. From the spectrum of $\mathrm{Cu}$ (II) bipy complexes, it performs that the characteristic of mononuclear copper complexes with axial symmetry, and lakes the hyperfine splitting like concentrated solid $\mathrm{Cu}$ (II) complexes. The g values provided inconstant information is reported by the modulation $\mathrm{G}=\left(\mathrm{g}_{\mid}-2\right) /\left(\mathrm{g}_{\perp}-2\right)$, that use full in measuring the exchange interaction between copper(II) centers has been considered in the polycrystalline solid, The analyses of spectra gives $\mathrm{g}_{\mathrm{l}}=$ 2.126 and $\mathrm{g}_{1}=2.108$ values for the $\mathrm{Cu}$ (II)bipy and $\mathrm{Cu}(\mathrm{II})$ phen complexes, respectively (Martins et al., 2016). In the causes, if $G$ $>4$, an expression that conversion interaction is insignificant, $G$ $<4$ it indicates the important significant between copper(II) ions. Our present paper study, the obtained ' $G$ ' value, suggest that is appreciable exchange interaction between copper(II) ions. 


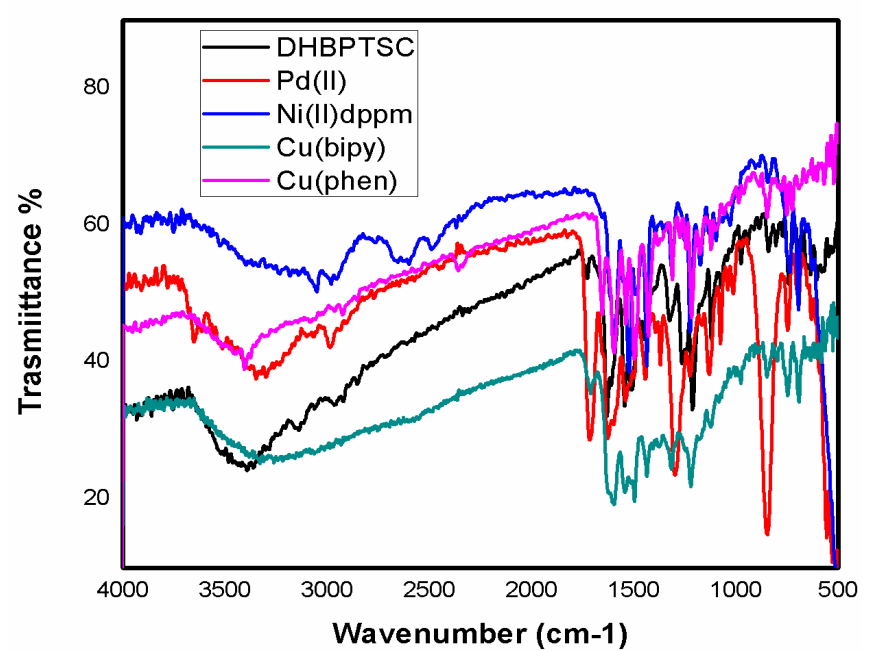

Fig. 3: FT-IR spectra of DHBPTSC, $\mathrm{Pd}(\mathrm{II}), \mathrm{Ni}(\mathrm{II})$-dppm, $\mathrm{Cu}(\mathrm{II})$-bipy, $\mathrm{Cu}(\mathrm{II})$ phen Complexes respectively.

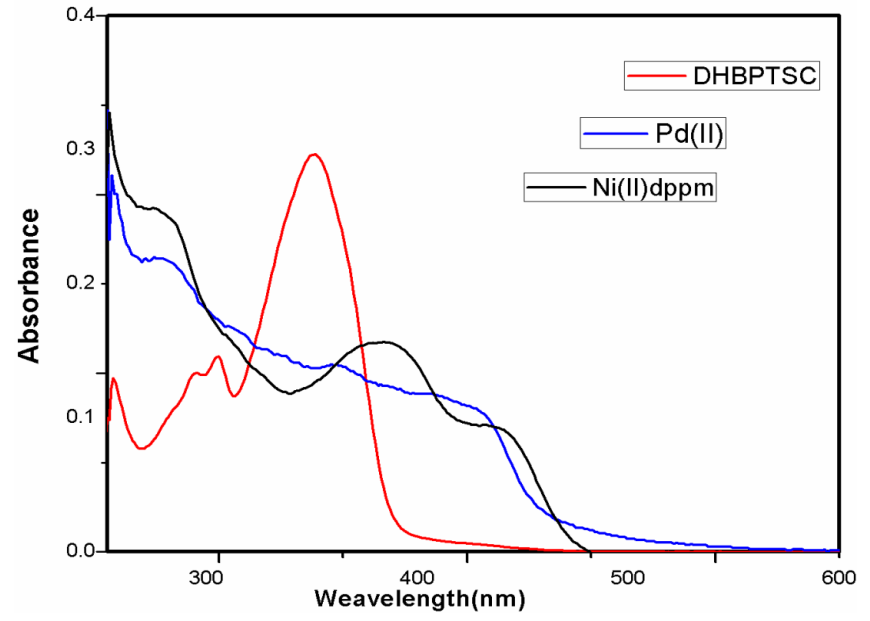

Fig. 4: Electronic absorption spectrum of the DHBPTSC, Pd(II) and Ni(II)dppm complexes.

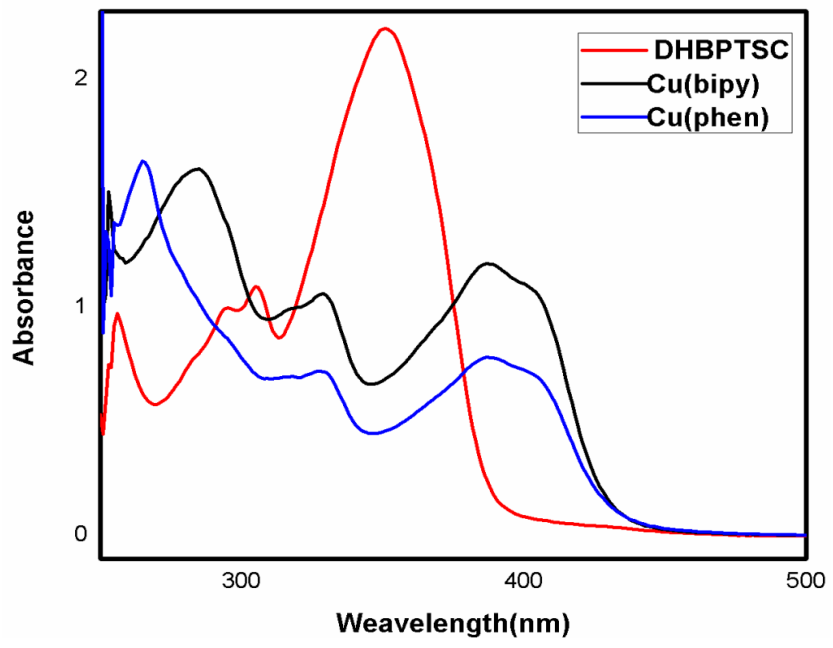

Fig. 5: Electronic absorption spectrum of the DHBPTSC, $\mathrm{Cu}(\mathrm{II})$-bipy, and $\mathrm{Cu}$ (II)-phen complexes.

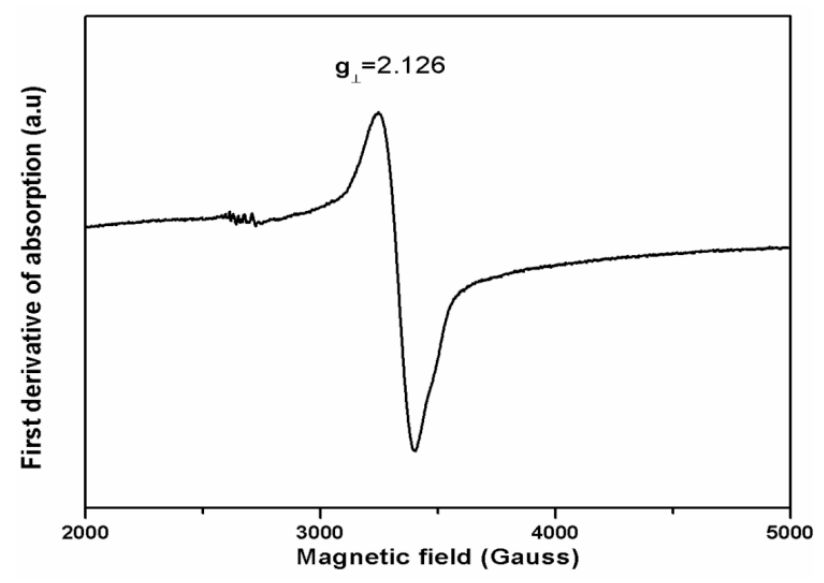

Fig. 6: X-band EPR spectrum of $\mathrm{Cu}(\mathrm{II})$-bipy complex.

\section{BIOLOGICAL STUDIES}

\section{Anti-microbial activity}

Antimicrobial activity of the synthesized ligand and metal complexes were tested against for different gram positive and negative bacteria. The activity of the ligand and their $\mathrm{Pd}(\mathrm{II}), \mathrm{Ni}(\mathrm{II}) \mathrm{dppm}, \mathrm{Cu}(\mathrm{II})$ bipy, and $\mathrm{Cu}(\mathrm{II})$ phen complexes were compared with criterion antibiotic streptomycin. The quantity of minimum inhibitory concentration (MIC) is the least concentration of transparent development after overnight incubation. Modified agar well diffusion method was used to find out the MIC values tabulated in Table 3 . The Ni(II)dppm complexes shown excellence effect against both gram-negative and are positive bacteria. However, other compounds have moderate activity against all organisms. $\mathrm{Cu}$ (II)-bipy shown an excellent effect against gram-negative $\mathrm{k}$. pneumonia. The chelation theory explains the reason behind the better activity of these thiosemicarbazone complexes (Agh-Atabay et al., 2005), the polarity of the metal ion is determined to be minimized to an advanced level, due to the responsibility of the ligand and unfinished of positive charge of the metal ion with donor groups especially with sulfur-nitrogen donors. Finally, included in the development of antibacterial activity for all compounds are in the order of $\mathrm{Ni}(\mathrm{II}) \mathrm{dppm}>$ $\mathrm{Cu}($ bipy $)>\mathrm{Cu}($ phen $)>\mathrm{Pd}(\mathrm{II})>$ ligand.

\section{Antifungal activity}

The preliminary antifungal activity of the DHBPTSC and its $\mathrm{Cu}$ (II)bipy, $\mathrm{Cu}$ (II)phen $\mathrm{Pd}(\mathrm{II})$, and $\mathrm{Ni}$ (II)dppm complexes were performed tested in vitro against three different fungal strains. The activities of the ligand and its complexes were parallel with standard antibiotic Fluconazole and shown in Table 4. On comparing the antifungal activity of the synthesized ligand and its metal complexes, it is observed that the metal complexes are capable of exhibiting higher antifungal activity than the free ligand. The antifungal activity of the increase in antifungal activity was better explained on the basis of chelation theory. All the complexes have been proved to be the better antifungal activity against the fungal strain $A$. niger and Rhizopus. $\mathrm{Cu}$ (II)-bipy has been proved to be the showed better antifungal activity against $A$. niger. However, none of the complexes display effective against $A$. flavus. The way of action may interfere the formation of a 
hydrogen bond through the azomethine nitrogen atom with the active centers of the cell constituents. The fungi conclusion in involvement through common cell procedure (Goñi et al., 2009; Chandra et al., 2009).

Table 3: Antibacterial activity of DHBPTSC and their Pd(II), Ni(II)-dppm, Cu(II)-bipy and Cu(II)-phen complexes.

\begin{tabular}{|c|c|c|c|c|c|}
\hline Compound & B. subtilis & E. coli & P. fluorescens & К. рпеитопеа & S. aureus \\
\hline $\mathrm{L}$ & 0.3 & 0.4 & 0 & 1.7 & 0 \\
\hline $\mathrm{Pd}(\mathrm{II})$ & 0.5 & 0 & 0.6 & 0.8 & 0 \\
\hline Ni(II)dppm & 1.3 & 1.0 & 0.7 & 3.2 & 0.6 \\
\hline $\mathrm{Cu}(\mathrm{II})$ bipy & 0.3 & 0.9 & 0 & 2.5 & 0 \\
\hline $\mathrm{Cu}(\mathrm{II})$ phen & 0.6 & 0.6 & 0 & 0.9 & 0 \\
\hline Streptomycin & 2.3 & 1.2 & 0.7 & 3.1 & 2.4 \\
\hline
\end{tabular}

Table 4: Antifungal activity of DHBPTSC and their Pd(II) and Ni(II)dppm, $\mathrm{Cu}(\mathrm{II})$-bipy, $\mathrm{Cu}(\mathrm{II})$-phen, complexes.

\begin{tabular}{cccc}
\hline Compound & A. niger & A. flavus & Rhizopus \\
\hline L & & & 0 \\
Pd(II) & 1.2 & 0 & 0.4 \\
Ni(II)-dppm & 0.9 & 0 & 0.4 \\
Cu(II)-bipy & & & 0 \\
Cu(II)-phen & 2.0 & 0.7 & 0.6 \\
Fluconazole & 2.3 & 1.6 & 2.3 \\
\hline
\end{tabular}

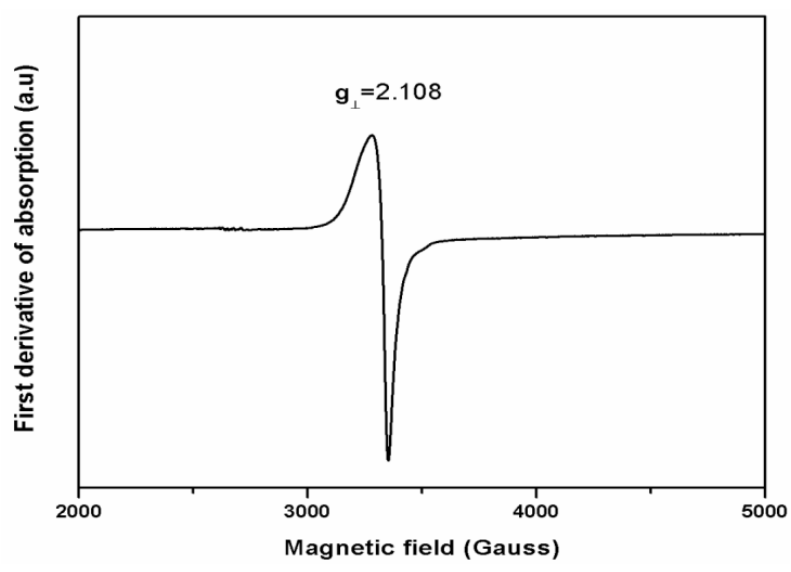

Fig. 7: X-band EPR spectrum of $\mathrm{Cu}(\mathrm{II})$-phen complex.

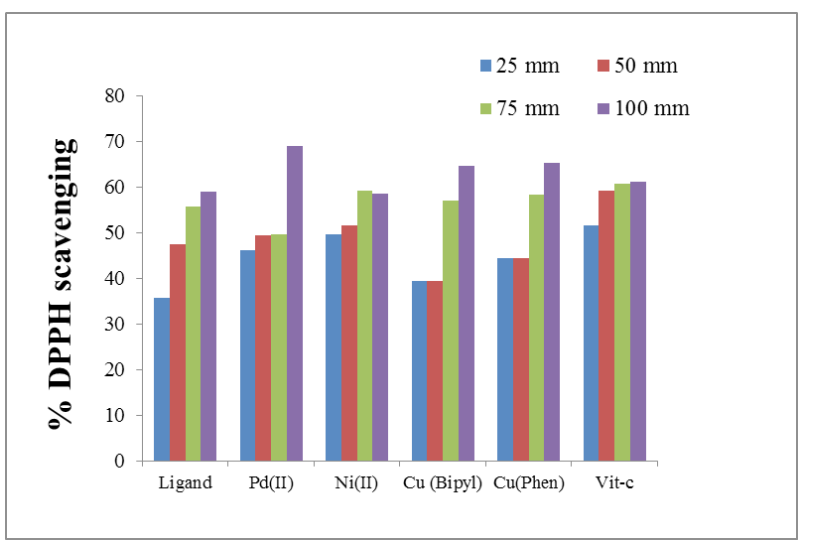

Fig. 8: DPPH Scavenging activity of ligand and their Pd(II), Ni(II)dppm, [Cu(II) bipy], and [Cu(II)phen] complexes.

\section{Anti-oxidant activity}

DPPH method is a prompt, simple and inexpensive method to measure the antioxidant ability of natural or synthesized compounds in vitro. The postulate for the reduction of DPPH free radicals is that the antioxidant reacts with stable free radical DPPH and reorganize it to 1,1 diphenyl-2-picrylhydrazine (Baraca et al., 2001). It shows the visible spectrum due to the presence of an unpaired electron occupation of a free radical scavenger the electron becomes paired off and absorbance decreases with respect to the number of electron capture higher. The free ligand exhibited comparative activity in DPPH scavenging as seen in the case of standard antioxidant Vitamin-C. All the complexes demonstrate good antioxidant properties in a concentration-dependent manner as shown in the Figure 8. Moreover, $\mathrm{Pd}(\mathrm{II})$ complex shown better activity than the standard Vitamin-C.

\section{CONCLUSIONS}

Synthesis of $\mathrm{Pd}(\mathrm{II}), \mathrm{Ni}(\mathrm{II}) \mathrm{dppm}$ and [Cu(II)bipy/phen] complexes with the ligand of 2,4-dihydroxybenzaldehyde-4phenyl-3-thiosemicarbazone and were characterized by different spectral characterization methods. The IR and NMR spectroscopy provided a convenient approach to elucidate the structure of the synthesized compounds. The electronic spectral studies suggested that $\mathrm{Pd}(\mathrm{II})$ complex has found to be square planar, EPR spectrum of each complex has confirmed the existence of characteristic of the $\mathrm{Cu}$ (II) ion with axial symmetry. Further, the investigations are underway the antibacterial and antifungal activities of the synthesized ligand its metal complexes shown moderate activity and $\mathrm{Pd}(\mathrm{II})$ complex appeared excellence antioxidant activity.

\section{ACKNOWLEDGMENTS}

I am thankful to Prof. Samar K. Das, School of Chemistry, University of Hyderabad, Hyderabad, for his guidance and permitting to carry out the present research work in his laboratory with his kindness and generosity. I also extend my thanks to UGC Networking Resource Center, University of Hyderabad, Hyderabad, India for providing necessary facilities for characterization of the compounds.

\section{REFERENCES}

Scovill JP, Klayman DL, Franchino CF. 2-acetylpyridine thiosemicarbazones. 4. Complexes with transition metals as antimalarial and antileukemic agents. J. Med. Chem. 1982; 25:1261-1264. 
Hu WX, Zhou W, Xia CN, Wen X. Synthesis and anticancer activity of thiosemicarbazones. Bioorg. Med. Chem. Lett. 2006; 16:2213-2218.

Belwal S, Seema Fahmi N, Singh RV, Synthesis and structural aspects of aluminium(III)imine complexes. Ind. J. Chem. 1999; 38A:596600 .

Casas JS, Garcia-Tasende MS, Sordo J. Main group metal complexes of semicarbazones and thiosemicarbazones. A structural review. Coord. Chem. Rev. 2000; 209:197-261.

Offiong OE, Martelli S. Antibacterial Activity of Metal Complexes of Benzil and Benzoin Thiosemicarbazones. Farmaco. 1994; 49:513.

Singh NK, Srivastava A, Sodhi A, Ranjan P. In vitro and in vivo antitumour studies of a new thiosemicarbazide derivative and its complexes with 3d-metal ions. Transition Met. Chem. 2000; 25: 133-140.

Garcia CC, Brousse BN, Carlucci MJ, Moglioni AG, Martins MA, Moltrasio GY, D'Accorso NB, Damonte EB. Antivir. Chem. chemother. 2003; 14:99.

Mishra D, Naskar S, Drew MGB, Chattopadhyay SK, Synthesis, spectroscopic and redox properties of some ruthenium(II) thiosemicarbazone complexes: Structural description of four of these complexes. Inorg. Chim. Acta. 2006; 359(2):585-592.

Prasad S, Agarwal RK. Cobalt(II) complexes of various thiosemicarbazones of 4-aminoantipyrine: syntheses, spectral, thermal and antimicrobial studies. Transition Met. Chem. 2007; 32:143-149.

Singh NK, Singh SB, Srivastava A, Singh SM, Spectral, magnatic and biological studies of 1,4-dibenzoyl-3-thiosemicarbazide complexes with some first row transition metal ions. Proceedings of the Indian Academy of Sciences. (Chem. Sci.). 2001; 113:257-273.

Kizilcikh I, Ulkuseven B, Dasdemir Y, Akkurt B. Zn(II) and Pd(II) Complexes of Thiosemicarbazone-S-alkyl Esters Derived from 2/3-formylpyridine. Synth. React. Inorg. Metal-Org. Chem. 2004; 34:653-665.

Chandra S, Sangeetika C, Rathi A. A magnetic and Spectral Studies on Copper(II) Complexes of NO and N-S donor ligands. J. Saudi Chem. Soc. 2001; 5:175-182.

Campbell MJM. Transition metal complexes of thiosemicarbazide and thiosemicarbazones. Coord. Chem. Rev. 1975; 15:279-319.

Padhye S, Kauffman GB. Transition metal complexes of semicarbazones and thiosemicarbazones. Coord. Chem. Rev. 1985; 63:127-160.

West DX, Liberta AE, Padhye SB, Chikate RC, Sonawane PB, Kumbhar AS, Yerande RG. Thiosemicarbazone complexes of copper(II): structural and biological studies, Coord. Chem. Rev. 1993; 123:49-71.

Singh S, Athar F, Maurya MR, Azam A. Cyclooctadiene Ru(II) complexes of thiophene-2-carboxaldehyde-derived thiosemicarbazones: synthesis, characterization and antiamoebic activity. Eur. J. Med. Chem. 2006; 41(5):592-598

Sahin M, Bal-Demirci T, Pozan-Soylu G, Ülküseven B. Synthesis, characterization and thermal decomposition of dioxouranium(VI), complexes with N1,N4-diarylidene-S-propyl-thiosemicarbazone: Crystal structure of $[\mathrm{UO} 2(\mathrm{LI})(\mathrm{C} 4 \mathrm{H} 9 \mathrm{OH})]$. Inorganica Chimica Acta 2009; $362: 2407-2412$

Bermejo E, Castineiras A, Pérez T, Carballo R, Hiller W. Synthesis and Structural Characterization of Metal Complexes of 2-formylpyrrole- ${ }^{4} \mathrm{~N}$-ethylthiosemicarbazone $\left(4 \mathrm{EL}_{1}\right)$ and 2-acetylpyrrole- ${ }^{4} \mathrm{~N}$ ethylthiosemicarbazone (4EL ${ }_{2}$ ) Anorg Z. Allg. Chem. 2001; 627(10):23772385 .

John RP, Sreekanth A, Rajakannan V, Ajith TA, Kurup MRP. Synthesis, characterization and physiochemical information, along with antimicrobial studies of some metal complexes derived from an $\mathrm{ON}$ donor semicarbazone ligand. Polyhedron. 2004; 23:2549-2559.

Belicchi-Ferrari M, Bisceglie F, Casoli C, Durot S, Morgenstern-Badarau I, Pelosi G, Pilotti E, Pinelli S, Tarasconi P. Spectral Characterization and Antibacterial Activities of benzyloxybenzaldehy dethiosemicarbazone,3,4-ydroxybenzaldehydeisonicotinoylhydrazone hydroxybenzaldehydeisonicotinoylhydrazone and their Transitional Metal Complexes J. Med. Chem. 2005; 5:1671-1675.

Gulea A, Poirier D, Roy J, Spinu S, Coziri N, Birca M, Tapcov V. Anticancer effect of sulfanilamide complexes of $\mathrm{Cu}(\mathrm{II})$ with thiosemicarbazones of substituted salicylic aldehydes. Actes du Colloque Franco-Roumain de Chimie Applique, 3rd Bacau, Romania 2004; 68:22-26.

Birca M, Tapcov V, Prisacari V, Gulea A, Buraciova S. Synthesis and antimicrobial properties of Cucomplexes with thiosemicarbazones of substituted salicylic aldehydes. Actesdu Colloque Franco-Roumain de Chimie Applique, 3rd Bacau, Ramania 2004; 44:22-26.

Sampath K, Sathiyaraj S, Jayabalakrish-nan C, Evaluation of DNA-binding, DNA cleavage, antioxidant and cytotoxic activity of mononuclear ruthenium(II) carbonyl complexes of benzaldehyde 4-phenyl3-thiosemicarbazones Spectochim. Acta Part A. 2013; 115:287.

Yudhvir K. Bhoon, Magnetic and EPR properties of Mn(II), $\mathrm{Fe}(\mathrm{III}), \mathrm{Ni}(\mathrm{II})$ and $\mathrm{Cu}(\mathrm{II})$ complexes of thiosemicarbazone of $\alpha$-hydroxy- $\beta$ napthaldehyde. Polyhedron. 1983; 2(5):365-368

West DX, Deborah S. Galloway, Transition metal ion complexes of the S-methyldithiocarbazate prepared from 2-acetylpyridine. Transition Met. Chem. 1988; 13(6):195-199.

Lobana TS, Indoria S, Jassal AK, Kaur H, Arora DS, Jasinski JP. Synthesis, structures, spectroscopy and antimicrobial properties of complexes of copper(II) with salicylaldehyde N-substituted thiosemicarbazones and 2,20-bipyridine or 1,10-phenanthroline. Eur. J. Med. Chem. 2014; 76:145-154.

Lobanaa TS, Kumaria P, Hundala G, Butcherb RJ, Castineirasc A, Akitsud T. Inorganica Chimica Acta. 2013; 394:605-615.

Jagadeesh M, Lavanya M, Kalangi SK, Sarala Y, Ramachandraiah C, Varada Reddy A. Spectroscopic characterization, antioxidant and antitumour studies of novel bromo substituted thiosemicarbazone and its copper(II), nickel(II) and palladium(II) complexes Spectrochimica Acta Part A: Molecular and Biomolecular Spectroscopy. 2015; 135:180-184

Martins DA, Gouvea LR, Muniz GSV, Louro SRW, Batista DDGJ, Soeiro MDNC, Letícia R. Teixeira 1 Bioinorganic Chemistry and Applications. Volume 2016, Article ID 5027404, 11 pages.

Agh-Atabay NM, Dulger B, Gucin F. Structural characterization and antimicrobial activity of 1,3-bis(2-benzimidazyl)-2-thiapropane ligand and its $\mathrm{Pd}(\mathrm{II})$ and $\mathrm{Zn}(\mathrm{II})$ halide complexes. Eur. J. Med. Chem. 2005; 40:1096-1102.

Goñi P, López P, Sánchez C, Gómez-Lus R, Becerril R, Nerín C. Antimicrobial activity in the vapour phase of a combination of cinnamon and clove essential oils. Food Chemistry. 2009; 116:982-989.

Chandra S, Parmar S, Kumar Y. Synthesis, Spectroscopic, and Antimicrobial Studies on Bivalent Zinc and Mercury Complexes of 2-Formylpyridine Thiosemicarbazone Hindawi Publishing Corporation. Bioinorganic Chemistry and Applications. Volume 2009, 1-6, Article ID 851316

Baraca A, Tommasi N.D, Bari L.D, Pizza C, Politi M, Morelli I. Antioxidant principles from Bauhinia terapotensis, J. Nat. Prod. 2001; 64:892-895.

How to cite this article:

Kumar VA, Sarala Y, Siddikha A, Vanitha S, Babu S, Reddy AV. Synthesis, Characterization Antimicrobial and Antioxidant Activities of 2,4-dihydroxybenzaldehyde-4-phenyl-3thiosemicarbazone (DHBPTSC) and its Pd(II), Ni(II)dppm Mixed Ligand and $\mathrm{Cu}$ (II) Complex having Heterocyclic Bases. J App Pharm Sci, 2018; 8(04): 071-078. 